\title{
Using Quality Function Deployment Approach to Design Ready to Drink Beverage Bottles
}

\author{
Didi Junaedi, Alur Pogowonto \\ Faculty of Engineering \\ Industrial Engineering Department \\ University of Mercu Buana (Universitas Mercu Buana) \\ Jakarta, 11650 \\ Indonesia
}

\begin{abstract}
Due to its role and usefulness in enhancing the product's consistency of beverage product, ready to drink (RTD) packaging is essential and has the appeal. In the beverage industry, competition in packaging is very intense. The practicality requirements promote new beverage packaging bottles that meet customer needs using the Quality Function Deployment (QFD) method. Ready to drink (RTD) category bottle is the design of beverage bottles produced. The choice of methods for the QFD approach is based on consumers' participation in the product design sequence as early as possible to ensure that the product will please customers. Research started with the dissemination of the initial questionnaire, the preparation of the customer's speech, the dissemination of the second questionnaire, the determination of the customer's needs, the decision on technical characteristics, the formation of the house of quality (HOQ), and the production of a visualized design. Round, pet (Polyethylene Terephthalate), bottle height 175 $\mathrm{mm}$, bottle base diameter $61.65 \mathrm{~mm}$, bottle body diameter 59.95 on the bloated body is the resulting RTD beverage bottle shape. In comparison, the diameter of the shrinking body in the middle is $53.24 \mathrm{~mm}$, the height of the neck-to-hole is $15.63 \mathrm{~mm}$, the diameter of the hole is $24.38 \mathrm{~mm}$, the diameter of the cap is $30.63 \mathrm{~mm}$, the weight of the light bottle is 20 grams, the width of the label is $40 \mathrm{~mm}$, the length of the label is $100 \mathrm{~mm}$ and the color of the blue and green label with flip and slide versions. The innovation in the design of this RTD beverage bottle is that by separating the two sides vertically, it can accommodate two types of drinks in one bottle ( 2 in 1 bottle), each side can accommodate $250 \mathrm{ml}$, and the suggested types of drinks are mineral water and tea from the survey results.
\end{abstract}

Key Words: Product Design, Packaging, Ready to Drink (RTD), Quality Function Deployment (QFD), House of Quality (HOQ).

\section{INTRODUCTION}

The company must please its consumers to win the market by offering better goods than its competitors. Companies that have long dominated the market for packaged drinks, as in Figure 1, different types of beverage goods. Bottled water as RTD (Ready to Drink) called in the beverage industry. This RTD drink comprises a wide variety of drinks that can generally be classified as RTD Water (mineral water), RTD Tea, RTD Carbonates. RTD Water has the highest percentage in the first order of 85.1 percent, and the second place is RTD Tea 8.7 percent, the third-place RTD Carbonates 3.0 percent, and the other fourth-place RTD 3.2 percent, based on 2014 Soft Drinks Industry Association (ASRIM) results. Other types of soft drinks, such as coffee, juice, energy drinks, and fitness, are other RTDs. 


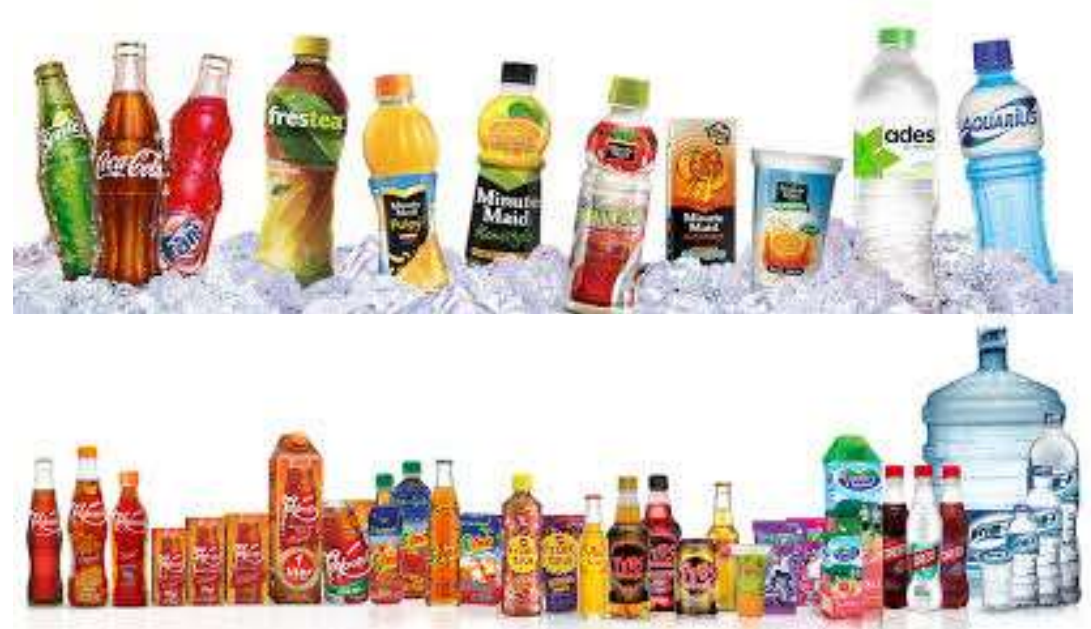

Figure 1 Examples of Manufacturers of Packaged Beverages with Various Product Variants

Source: cocacola.co.id, sinarsosro.co.id

As shown in the data above, this RTD beverage industry shows the potential to continue to expand. This potential can also be motivated by the immediate changes in young people's lifestyles who like to gather and work outdoors[1]. Consumer rivalry, both locally and multi-nationally, often offers the business more product variations and creates more value or excellence for the product. The packaging is one of the five keys to the successful marketing of food products, and the other is price, product, place, and promotion[2]. Packaging also creates a difference in helping customers decide to pick one of the same works[3], [4].

A product development concept based on customer demand is product creation with the QFD method[5], [6]. The QFD approach has many benefits that companies can obtain, such as being able to schedule quality levels, benchmarking with other companies to understand knowledge about competitors so that they can design and manufacture different products and have superior quality, can minimize design changes resulting from less maximum design, minimize production time and costs, and can broaden the market according to customers wishes, QFD is expected to deliver a revolutionary beverage packaging bottle design.

The characteristics of customer needs for RTD bottle packaging can be known through this research and how the design of beverage packaging bottles is focused on consumer feedback. The aim of deciding characteristics is to understand the consumer's taste for the product. This can be achieved by means of a process (Quality Function Deployment), i.e., by converting the preferences of the user into customer needs attributes corresponding to technical characteristics[7], [8]. QFD is a systematic matrix that illustrates the approach taken to quality product design.

\section{METHODOLOGY}

The type of data used in this study is quantitative data, which is data in the form of numbers in the form of information required by the consumer. In the context of data from the questionnaire, the primary data source used is the data source, while the secondary data used in this analysis is derived from other literature. Non-probability sampling with unintended sampling is the sampling approach this study uses. Using the Bernoulli sample approximation or proportion method to assess the number of samples in this analysis, the size or number of the total population is unknown[9], [10]. The formula calculates the number of proportional sample methods as follows:

$\mathrm{n}=\frac{(Z \alpha / 2)^{2} \cdot p \cdot q}{e^{2}}$

Where:

$\mathrm{n}=$ Minimum sample count

$\mathrm{Z}=$ Normal distribution value (viewed on normal distribution table)

$\alpha=$ Level of significance $(95 \%)$

$p=$ Proportion of population $(70 \%)$

$q=1-\mathrm{p}$

$e=$ Error tolerance $(10 \%)$ 
The results of the estimation using the Bernoulli method on the number of test samples are as follows:

$$
\begin{aligned}
\mathrm{n} & =\frac{\left(Z_{\alpha / 2}\right)^{2} \cdot p \cdot q}{e^{2}} \\
& =\frac{(1,96)^{2} \cdot 0,7 \cdot 0,3}{(0,1)^{2}} \\
& =\frac{0,806736}{0,01} \\
& =80.7 \sim 81 \text { samples }
\end{aligned}
$$

So the minimum number of samples is as many as 81 samples or 81 respondents. In this study, 85 respondents were taken. The questionnaire that has been disseminated and collected next is tested its validity and reliability[11]. In testing the validity and reliability of data, researchers used tools in the form of computer software.

\section{RESULT AND DISCUSSION}

Consumer perception (voice of customer) regarding RTD beverage bottles' packaging obtained eight perceptions from the preliminary research results through a questionnaire, namely the lid, shape, label, dimensions, capacity, label design, color, and label detail. Benchmarks of some scientific literature related to beverage packaging have been focused on that understanding. So, 15 characteristics of customer needs were obtained. Packaging dimensions, packaging color, packaging style, packaging shape, non-perishable packaging, safe packaging for health, easy to hold and carry packaging, recyclable packaging, beverage type version, packaging capacity and volume of beverages, and packaging can protect beverage products, packaging weight, easy to open and close lids, easy to leak cap, packaging labels to protect beverage products, packaging weight, easy to open and close lids,

Then, in the questionnaire on consumer needs, 15 attributes of consumer needs were evaluated to obtain the interests of the characteristics of the consumer needs found. From the consumer needs questionnaire answered by 88 respondents, 15 consumer needs, each respondent answered statements. Five response options are given for each report; namely, VNI= Very Not Important, $\mathrm{NI}=$ Not Important, IE= Important Enough, I= Important, VI= Very Important.

The next step after obtaining answers from respondents is to assess the data's validity and reliability. One invalid attribute of 15 attributes in the second attribute, namely the color of the packaging, from the test results of the customer requires. This questionnaire relied on reliability test results when approached via the Cronbach Alpha statistical test.

The number of customer needs characteristics is reduced to 14 facts from the test results of validity and reliability data due to invalid need attributes. The indicated points are valid and reliable as follows: packaging measurements, packaging design, packaging shape, non-perishable packaging, health-safe packaging, packaging that is easy to hold and carry, recyclable packaging, beverage type model, packaging capacity and volume of beverage, packaging that can protect beverage products, packaging weight, easy to open and close lids, easy to leak cap, packaging laboratory length, packaging that can protect beverage products, packaging weight,

After the customer needs attribute is calculated, the importance of the interests of each stage of the needs of the consumer is calculated. To measure the amount of interest is to multiply each respondent's response by the weight of each solution. VNI response weight (Very Not Important) 1, NI weight (Not Important) 2, IE weight (Important Enough) 3, I (Important) 4 weight, and VI (Very Important) weight 5.

The results of $\mathrm{VNI}=1, \mathrm{NI}=10, \mathrm{IE}=38, \mathrm{I}=28$, and $\mathrm{VI}=11$ were obtained from the packaging dimension attribute of the respondent's response in Table 1 . The value of the packaging dimension $=((1 \times 1)+(2 \times 10)+(3 \times 38)+(4 \times 28)+(5 \times 11))$ is divided by 88 (number of respondents), which results in an interest value of 3.43 for the packaging attribute, as shown in Table 2.

Table 1 Customer Need Questionnaire Results

\begin{tabular}{|c|l|c|c|c|c|c|c|}
\hline No & \multicolumn{1}{|c|}{ Attributes of Customer Needs } & VNI & NI & IE & I & VI & $\begin{array}{c}\text { Sample } \\
\text { Count }\end{array}$ \\
\hline 1 & Packaging dimensions & 1 & 10 & 38 & 28 & 11 & 88 \\
\hline 2 & Packaging color & 13 & 35 & 28 & 10 & 2 & 88 \\
\hline 3 & Packaging design & 3 & 17 & 24 & 30 & 14 & 88 \\
\hline 4 & Packaging form & 3 & 13 & 22 & 32 & 18 & 88 \\
\hline 5 & Packaging is not easily damaged & 2 & 14 & 19 & 32 & 21 & 88 \\
\hline
\end{tabular}


International Journal of Advances in Scientific Research and Engineering (ijasre), Vol 6 (10), October -2020

\begin{tabular}{|c|l|c|c|c|c|c|c|}
6 & Safe packaging for health & 0 & 11 & 19 & 28 & 30 & 88 \\
\hline 7 & The packaging is easy to hold and carry & 3 & 10 & 35 & 26 & 14 & 88 \\
\hline 8 & Recyclable packaging & 0 & 10 & 9 & 31 & 38 & 88 \\
\hline 9 & Beverage type variants & 3 & 6 & 22 & 38 & 19 & 88 \\
\hline 10 & $\begin{array}{l}\text { Packaging capacity and beverage } \\
\text { volume }\end{array}$ & 2 & 9 & 35 & 28 & 14 & 88 \\
\hline 11 & $\begin{array}{l}\text { Packaging can protect beverage } \\
\text { products }\end{array}$ & 2 & 17 & 24 & 31 & 14 & 88 \\
\hline 12 & Packaging weight & 1 & 13 & 14 & 40 & 20 & 88 \\
\hline 13 & Bottlecap easy to open and close & 2 & 12 & 16 & 26 & 32 & 88 \\
\hline 14 & The bottle cap is not easy to leak & 2 & 7 & 15 & 24 & 40 & 88 \\
\hline 15 & $\begin{array}{l}\text { Packaging labels can provide } \\
\text { information }\end{array}$ & 2 & 13 & 24 & 35 & 14 & 88 \\
\hline
\end{tabular}

Source: Processed Primary Data, 2020

For the relative weight value of the attribute of the packaging dimension, obtained from 3.43 divided by 14 (the total number of customers requires characteristics), the relative weight value of the packaging dimension is $6.7 \%$ (Table 2).

Those customers' needs with technological characteristics capable of realizing the quality of packaging or bottles of RTD beverages should be addressed after the next customer has been identified. Through the analysis of relevant literature, as many as 24 technical characteristics were obtained from technical aspects to respond to the customer needs characteristics. The technical features of RTD beverage packaging or bottles are the height of the bottle, the base diameter of the bottle, bottle body diameter, neck to hole height, hole diameter, cap diameter, mineral water, and tea marker relief and motif on bottle body, bottle partition to separate drinks, round with middle slightly shrinking. The plastic bottle is quite thick, plastic material, ergonomic hand shape, recyclable plastic bottle, mineral water and tea, total capacity, resistant to cold temperature, lightweight, bottle cap working, bottle cap design, bottle cap material, bottle cap mold result, label width, label length, and last label color.

Like consumer requirements, by sorting the importance of technical attributes from the largest to the smallest quantity, technical characteristics can also be recognized as a priority. In Table 4, the emphasis of the overall technological features can be seen.

Table 2 Value of Interests of Each Attribute of Consumer Needs

\begin{tabular}{|c|l|c|c|}
\hline No & \multicolumn{1}{|c|}{ Customer Need } & Weight Importance & Relative Weight \\
\hline 1 & Packaging dimensions & 3,43 & 6,7 \\
\hline 2 & Packaging design & 3,40 & 6,6 \\
\hline 3 & Packaging form & 3,56 & 6,9 \\
\hline 4 & The packaging is not easily damaged & 3,64 & 7,1 \\
\hline 5 & Safe packaging for health & 3,88 & 7,6 \\
\hline 6 & The packaging is easy to hold and carry & 3,43 & 6.7 \\
\hline 7 & Recyclable packaging & 4,10 & 8,0 \\
\hline 8 & Beverage type variants & 3,73 & 7,3 \\
\hline 9 & Packaging capacity and beverage volume & 3,49 & 6,8 \\
\hline 10 & Packaging can protect beverage products & 3,43 & 6,7 \\
\hline 11 & Packaging weight & 3,74 & 7,3 \\
\hline 12 & Bottlecap easy to open and close & 3,84 & 7,5 \\
\hline 13 & The bottle cap is not easy to leak & 4,06 & 7,9 \\
\hline 14 & Packaging labels can provide information & 3,52 & 6,9 \\
\hline
\end{tabular}

Source: Processed Primary Data, 2020

The way the bottle cap works is the most critical priority in carrying out the design, based on the priority of technical characteristics in Table 4. On the other hand, the most recent value is the relief of mineral water and tea markers and motifs on the body of the container. 
International Journal of Advances in Scientific Research and Engineering (ijasre), Vol 6 (10), October -2020

Table 3 Customer Needs Priorities

\begin{tabular}{|c|l|c|c|}
\hline No & \multicolumn{1}{|c|}{ Customer Need } & $\begin{array}{c}\text { Weight } \\
\text { Importance }\end{array}$ & Priority \\
\hline 1 & Recyclable packaging & 4.10 & 1 \\
\hline 2 & The bottle cap is not easy to leak & 4.06 & 2 \\
\hline 3 & Safe packaging for health & 3.88 & 3 \\
\hline 4 & Bottlecap easy to open and close & 3.84 & 4 \\
\hline 5 & Packaging weight & 3.74 & 5 \\
\hline 6 & Beverage type variants & 3.73 & 6 \\
\hline 7 & The packaging is not easily damaged & 3.64 & 7 \\
\hline 8 & Packaging form & 3.56 & 8 \\
\hline 9 & $\begin{array}{l}\text { Packaging labels can provide } \\
\text { information }\end{array}$ & 3.52 & 9 \\
\hline 10 & $\begin{array}{l}\text { Packaging capacity and beverage } \\
\text { volume }\end{array}$ & 3.49 & 10 \\
\hline 11 & Packaging dimensions & 3.43 & 11 \\
\hline 12 & The packaging is easy to hold and carry & 3.43 & 12 \\
\hline 13 & $\begin{array}{l}\text { Packaging can protect beverage } \\
\text { products }\end{array}$ & 3.43 & 13 \\
\hline 14 & Packaging design & 3.40 & 14 \\
\hline
\end{tabular}

Source: Processed Primary Data, 2020

Determining customer needs and technological characteristics is the next step. This relationship aims to understand the strength of the relationship between technical features and customer requirements. There are three types of these relationships: stable relationships, moderate relationships, and poor relations. The three types of partnerships were weighted between customer desires and RTD beverages' packaging's technical characteristics. For stable relationships, the weight of the relationship between technical characteristics and customer needs is 9,3 for medium relationships, and 1 for poor relationships. The relation is shown in Figure 1. in the house of quality (HOQ). 


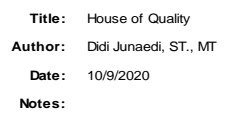

Author: Didi Junaedi, ST., MT

Notes:

\begin{tabular}{|c|c|c|}
\hline \multicolumn{3}{|c|}{ Legend } \\
\hline$\Theta$ & Strong Relationship & 9 \\
\hline 0 & Moderate Relationship & 3 \\
\hline $\boldsymbol{A}$ & Weak Relationship & 1 \\
\hline+ & Strong Positive Correlation & \\
\hline+ & Positive Correlation & \\
\hline - & Negative Correlation & \\
\hline $\boldsymbol{\nabla}$ & Strong Negative Correlation & \\
\hline $\boldsymbol{\nabla}$ & Objective Is To Mnimize & \\
\hline $\boldsymbol{\Delta}$ & Objective Is To Maximize & \\
\hline$x$ & Objective is To Hit Target & \\
\hline
\end{tabular}

$+$

$++$

\begin{tabular}{|c|c|c|c|c|c|c|c|c|c|c|c|c|c|c|c|c|c|c|c|c|c|c|c|c|c|c|c|c|}
\hline & & & & Column\# & 1 & 2 & 3 & 4 & 5 & 6 & 7 & 8 & 9 & 10 & 11 & 12 & 13 & 14 & 15 & 16 & 17 & 18 & 19 & 20 & 21 & 22 & 23 & 24 \\
\hline & 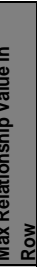 & 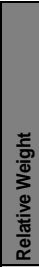 & 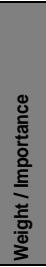 & 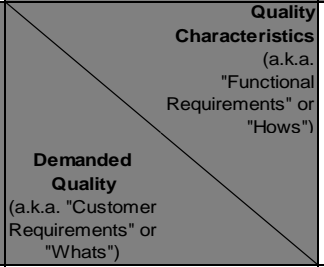 & 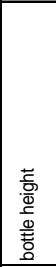 & 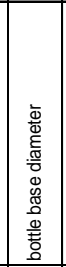 & 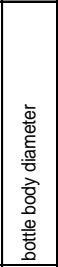 & 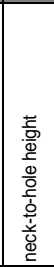 & 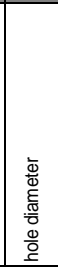 & 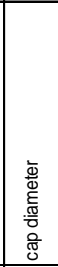 & 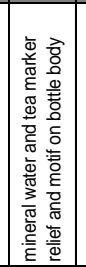 & 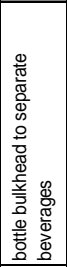 & 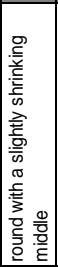 & 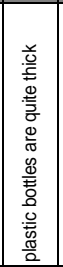 & 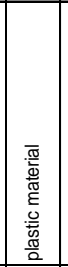 & 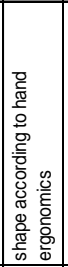 & 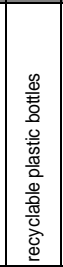 & 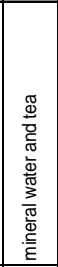 & 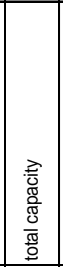 & 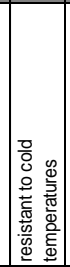 & 镸 & 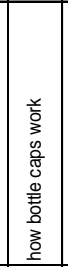 & 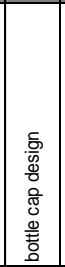 & 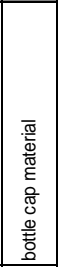 & 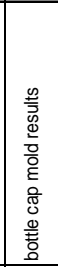 & 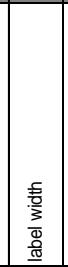 & 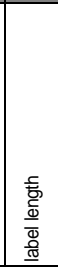 & $\begin{array}{l}\text { 흥 } \\
\frac{0}{\mathbb{d}} \\
\underline{d}\end{array}$ \\
\hline 1 & 9 & 6.7 & 3.4 & Packaging dimensions & $\odot$ & $\odot$ & $\Theta$ & $\odot$ & $\odot$ & $\Theta$ & & $\Delta$ & 0 & & & 0 & & & 0 & & $\Delta$ & $\Delta$ & $\Delta$ & & $\Delta$ & & & \\
\hline 2 & 9 & 6.6 & 3.4 & Packaging design & & & & & & & $\Theta$ & $\odot$ & $\Delta$ & & & $\Delta$ & & & $\Delta$ & & $\Delta$ & 0 & $\Delta$ & $\Delta$ & & & & \\
\hline 3 & 9 & 6.9 & 3.6 & Packaging form & & & & & & & & & $\Theta$ & & & 0 & & & & & $\Delta$ & $\Delta$ & & & & & & \\
\hline 4 & 9 & 7.1 & 3.6 & Packaging is not easily damaged & & & & & & & & & & $\Theta$ & 0 & & & & & $\Theta$ & & & & & & & & \\
\hline 5 & 9 & 7.6 & 3.9 & Safe packaging for health & & & & & & & & & & & $\Theta$ & & & & & & & & & & & & & \\
\hline 6 & 9 & 6.7 & 3.4 & Packaging is easy to hold and carry & & & & & & & & & 0 & & & $\Theta$ & & & & & & & & & & & & \\
\hline 7 & 9 & 8.0 & 4.1 & Recyclable packaging & & & & & & & & & & & $\Delta$ & & $\Theta$ & & & & & & & & & & & \\
\hline 8 & 9 & 7.3 & 3.7 & Beverage type variants & & & & & & & & & & & 0 & & $\Delta$ & $\Theta$ & $\Delta$ & $\Delta$ & & & & & & & & \\
\hline 9 & 9 & 6.8 & 3.5 & $\begin{array}{l}\text { Packaging capacity and beverage } \\
\text { volume }\end{array}$ & & & & & & & & & & & & & & & $\odot$ & & & & & & & & & \\
\hline 10 & 9 & 6.7 & 3.4 & $\begin{array}{l}\text { Packaging can protect beverage } \\
\text { products }\end{array}$ & & & & & & & & 0 & & $\odot$ & O & & & $\boldsymbol{\Delta}$ & & $\odot$ & & $\odot$ & $\odot$ & $\odot$ & $\odot$ & & & \\
\hline 11 & 9 & 7.3 & 3.7 & Packaging weight & & & & & & & & & & & & & & & & & $\Theta$ & & & & & & & \\
\hline 12 & 9 & 7.5 & 3.8 & Bottle cap easy to open and close & & & & & & & & & & & & & & & & & & $\Theta$ & $\odot$ & $\Theta$ & & & & \\
\hline 13 & 9 & 7.9 & 4.1 & Bottle cap is not easy to leak & & & & & & & & & & & & & & & & & & & & & $\Theta$ & & & \\
\hline & 9 & 6.9 & 3.5 & $\begin{array}{l}\text { Packaging labels can provide } \\
\text { information }\end{array}$ & & & & & & & & & & & & & & & & & & & & & & $\Theta$ & $\Theta$ & $\Theta$ \\
\hline & & & & Target or Limit Value & 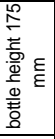 & 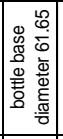 & 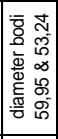 & 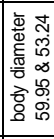 & 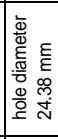 & 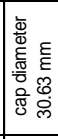 & 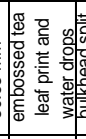 & 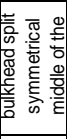 & 옴 & 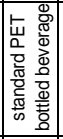 & 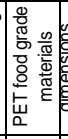 & 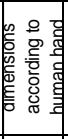 & 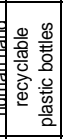 & 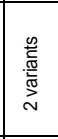 & 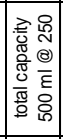 & 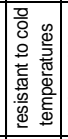 & 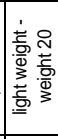 & 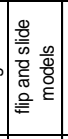 & 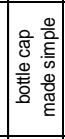 & 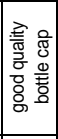 & 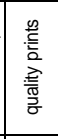 & 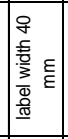 & 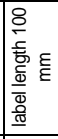 & 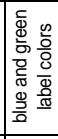 \\
\hline & & & & $\begin{array}{l}\text { Technical Difficulty } \\
(1=\text { Low, } 5=\text { High })\end{array}$ & 1 & 1 & 2 & 3 & 1 & 1 & 3 & 5 & 1 & 1 & 1 & 4 & 1 & 1 & 1 & 2 & 1 & 5 & 5 & 3 & 3 & 1 & 1 & 1 \\
\hline & & & & Max Relationship Value in & 9 & 9 & 9 & 9 & 9 & 9 & 9 & 9 & 9 & 9 & 9 & 9 & 9 & 9 & 9 & 9 & 9 & 9 & 9 & 9 & 9 & 9 & 9 & 9 \\
\hline & & & & $\begin{array}{c}\text { Weight / Importance } \\
\text { Relative Weight }\end{array}$ & \begin{tabular}{r|}
60.2 \\
2.7
\end{tabular} & \begin{tabular}{|c|}
60.2 \\
2.7 \\
\end{tabular} & \begin{tabular}{|c|}
60.2 \\
2.7 \\
\end{tabular} & $\frac{60.2}{2.7}$ & $\frac{60.2}{2.7}$ & $\frac{60.2}{2.7}$ & \begin{tabular}{|l}
59.7 \\
2.7
\end{tabular} & \begin{tabular}{|l|}
86.5 \\
3.9
\end{tabular} & \begin{tabular}{|c|}
109.3 \\
4.9 \\
\end{tabular} & \begin{tabular}{|c|}
124.2 \\
5.6
\end{tabular} & $\frac{139.4}{6.3}$ & \begin{tabular}{|c|}
107.8 \\
4.9 \\
\end{tabular} & \begin{tabular}{|c|}
79.3 \\
3.6 \\
\end{tabular} & $\frac{72.2}{3.3}$ & \begin{tabular}{c|c}
95.3 \\
4.3
\end{tabular} & \begin{tabular}{|c|}
131.4 \\
5.9
\end{tabular} & \begin{tabular}{|c|}
86.0 \\
3.9
\end{tabular} & $\frac{161.2}{7.3}$ & 2141.0 & $\frac{134.3}{6.1}$ & $\frac{138.2}{6.2}$ & $\begin{array}{ll}61.8 \\
28\end{array}$ & $\frac{61.8}{28}$ & \begin{tabular}{|c|}
61.8 \\
28 \\
\end{tabular} \\
\hline
\end{tabular}

Figure 1 House of Quality RTD Bottle Packaging

Source: Processed Primary Data, 2020

Next is to set the goal of each technical function attributes. This goal is to monitor each technical function to shape a design that meets consumers' needs. In deciding the objectives of this report, literature reviews and reviews are carried out via the packaging manufacturers' website and discussions with design experts, shown in Table 5, the effectively formulated label.

Table 4 Priority Technical Characteristics of RTD Beverage Packaging

\begin{tabular}{|c|l|c|c|}
\hline No & \multicolumn{1}{|c|}{ Technical Characteristics } & $\begin{array}{c}\text { Value of } \\
\text { Interest }\end{array}$ & Priority \\
\hline 1 & How Bottle Caps Work & 161.2 & 1 \\
\hline 2 & Bottle Cap Design & 141 & 2 \\
\hline 3 & Plastic Material & 139.4 & 3 \\
\hline 4 & Bottle Cap Mould Results & 138.2 & 4 \\
\hline
\end{tabular}


International Journal of Advances in Scientific Research and Engineering (ijasre), Vol 6 (10), October -2020

\begin{tabular}{|c|l|c|c|}
5 & Bottle Cap Material & 134.3 & 5 \\
\hline 6 & Resistant to Cold Temperatures & 131.4 & 6 \\
\hline 7 & Plastic Bottles are Quite Thick & 124.2 & 7 \\
\hline 8 & Round With A Slightly Shrinking Middle & 109.3 & 8 \\
\hline 9 & Shape According to Hand Ergonomics & 107.8 & 9 \\
\hline 10 & Total Capacity & 95.3 & 10 \\
\hline 11 & Bottle Bulkhead to Separate Beverages & 86.5 & 11 \\
\hline 12 & Light & 86 & 12 \\
\hline 13 & Recyclable Plastic Bottles & 79.3 & 13 \\
\hline 14 & Mineral Water and Tea & 72.2 & 14 \\
\hline 15 & Label Width & 61.8 & 15 \\
\hline 16 & Label Length & 61.8 & 16 \\
\hline 17 & Label Color & 61.8 & 17 \\
\hline 18 & Cap Diameter & 60.3 & 18 \\
\hline 19 & Bottle Height & 60.2 & 19 \\
\hline 20 & Bottle Base Diameter & 60.2 & 20 \\
\hline 21 & Bottle Body Diameter & 60.2 & 21 \\
\hline 22 & Neck-To-Hole Height & 60.2 & 22 \\
\hline 23 & Hole Diameter & 60.2 & 23 \\
\hline 24 & Mineral Water And Tea Marker Relief And Motif on The Bottle Body & 59.7 & 24 \\
\hline
\end{tabular}

Source: Processed Primary Data, 2020

The RTD bottled water packaging breakthrough is on the inside of the bottle and the bottle cap. Two symmetrical sections are divided into the bottle; the object of these two parts or two spaces is to accommodate two types of beverages. Mineral water and tea-flavored water are part of the idea of creating RTDdrink bottles. The findings of 9 respondents from 27 samples were collected from two forms of beverages from the distribution of questionnaires at the time of preliminary testing (Figures $2 \mathrm{a}$ and $2 \mathrm{~b}$ ), so it was agreed to bottle this RTD beverage kit for mineral water and tea-type drinks.

Table 5 Objectives of Each Distinctive Technical Characteristics

\begin{tabular}{|c|c|c|}
\hline No & Technical Characteristics & Objective \\
\hline 1 & Bottle height & bottle height $175 \mathrm{~mm}$ \\
\hline 2 & Bottle base diameter & bottle base diameter $61.65 \mathrm{~mm}$ \\
\hline 3 & Bottle body diameter & bottle body diameter 59.95 and $53.24 \mathrm{~mm}$ \\
\hline 4 & Meck-to-hole height & neck-to-hole height $15.63 \mathrm{~mm}$ \\
\hline 5 & Mole diameter & hole diameter $24.38 \mathrm{~mm}$ \\
\hline 6 & Cap diameter & cap diameter $30.63 \mathrm{~mm}$ \\
\hline 7 & $\begin{array}{l}\text { Mineral water and tea marker relief and motif on } \\
\text { the bottle body }\end{array}$ & embossed print of leaf motifs and water drops \\
\hline 8 & Bottle bulkhead to separate beverages & $\begin{array}{l}\text { an asymmetrical split of the middle of the } \\
\text { bottle }\end{array}$ \\
\hline 9 & Round with a slightly shrinking middle & Round \\
\hline 10 & Plastic bottles are quite thick & $\begin{array}{l}\text { standard thick beverage bottle PET } \\
\text { (Polyethylene Terephthalate) }\end{array}$ \\
\hline 11 & Plastic material & $\begin{array}{l}\text { PET material (Polyethylene Terephthalate) } \\
\text { food grade }\end{array}$ \\
\hline 12 & Shape according to hand ergonomics & $\begin{array}{l}\text { dimensions according to human hand } \\
\text { ergonomics }\end{array}$ \\
\hline 13 & Recyclable plastic bottles & recyclable plastic bottles \\
\hline 14 & Mineral water and tea & Two variants \\
\hline 15 & Total capacity & the total capacity of $500 \mathrm{ml} @ 250 \mathrm{ml}$ \\
\hline 16 & Resistant to cold temperatures & resistant to cold temperatures \\
\hline 17 & Light & lightweight - weighing 20 grams \\
\hline 18 & How bottle caps work & flip and slide models \\
\hline 19 & Bottlecap design & the lid is made simple \\
\hline
\end{tabular}


International Journal of Advances in Scientific Research and Engineering (ijasre), Vol 6 (10), October -2020

\begin{tabular}{|l|l|l|}
20 & Bottlecap material & quality bottle cap material \\
\hline 21 & Bottlecap mold results & quality prints \\
\hline 22 & Label width & Label width $40 \mathrm{~mm}$ \\
\hline 23 & Label length & Label length of $100 \mathrm{~mm}$ \\
\hline 24 & Label color & Blue and green label colors \\
\hline
\end{tabular}

Source: Processed Primary Data, 2020

Furthermore, the bottle cap is the other invention besides the notion of 2 drinks in 1 bottle. Since it requires two types of beverages, a good lid must be designed to not leak or clash between the two drinks. The expectation is that it can be easily opened and closed (Figure $2 \mathrm{~b}$ ), the concept-designed bottle cap flips, and slides.

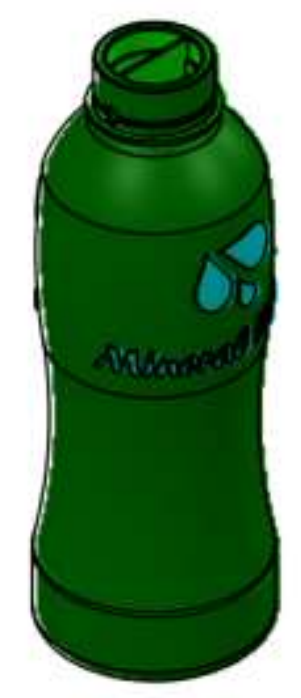

(2a)

Figure 2a Design 3 Dimensional Bottle Packaging RTD

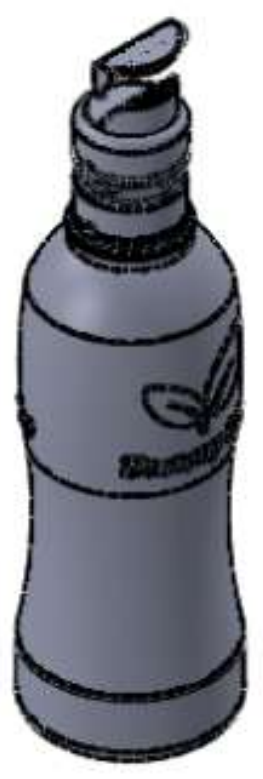

(2b)

Figure 2b Design 3 Dimensional Bottle Cap Packaging RTD 


\section{CONCLUSION}

Characteristics of the consumer's need for beverage packaging bottles ready to drink are as follows: Packaging measurements, Packaging style, Packaging form, Non-perishable packaging, Health-safe packaging, Simple to hold and carry packaging, Recyclable packaging, Beverage type variants, Packaging capacity and volume of beverage, packaging can protect beverage goods, Packaging weight, The lid is simple, Bottle height $175 \mathrm{~mm}$, bottle base diameter $61.65 \mathrm{~mm}$, bottle body diameter 59.95 and $53.24 \mathrm{~mm}$, neck height to hole $15.63 \mathrm{~mm}$, hole diameter $24.38 \mathrm{~mm}$, cap diameter $30.63 \mathrm{~mm}$, bottle base diameter $61.65 \mathrm{~mm}$, bottle body diameter 59.95 and $53.24 \mathrm{~mm}$, neck height to hole $15.63 \mathrm{~mm}$, tea box diameter $24.38 \mathrm{~mm}$, cap diameter $30.63 \mathrm{~mm}$, printed leaf motif and water drops near the bottleneck (tea box) are the following technical features or specifications.

\section{ACKNOWLEDGMENT}

Thank you to the Mercu Buana University Research Centre, which has sponsored this research.

\section{REFERENCES}

[1] Azrifirwan, T. Djatna, S. Maarif, M. Ushada, and Endang Warsiki, "Model Decisions For Knowledge Part Design Packaging Formation of Consumer Perception," J. Teknol. Ind. Pertan., vol. 27, no. 3, pp. 271-280, 2017, doi: 10.24961/j.tek.ind.pert.2017.27.3.271.

[2] J. B. Lawlor, R. Deliza, H. R. Moskowitz, and M. Reisner, Packaging Research in Food Product Design and Development, 1st ed. Wiley-Blackwell, 2009.

[3] H. Farley, "The importance of packaging design for own-label food brands," Artic. Int. J. Retail Distrib. Manag., vol. 35, no. 9, pp. 677-690, Jul. 2007, doi: 10.1108/09590550710773237.

[4] Y. Ekawati and F. Widjaja, "Perencanaan Proses Produksi Kemasan Sirup Wortel Menggunakan Metode Quality Function Deployment," J. Ilm. Tek. Ind., vol. 5, no. 2, pp. 104-111, 2017.

[5] A. F. Haqqoni, I. Iftadi, and A. W. Jauhari, "Identifikasi Kebutuhan Pelanggan Dan Karakteristik Teknis Dalam Perancangan Kemasan Produk Teh Seduh,” in Seminar Nasional Sains dan Teknologi ke 6, 2015, pp. 31-36.

[6] E. Nina and S. Yuliani, Development of Prototype Ergonomic Reflexology Vest (ERV) for Improving the Quality and Performance Features. 2019.

[7] A. Trimarjoko, A. Puspa Wirani, and H. H. Purba, "Perancangan dan Pengembangan Produk Ban Hemat Bahan Bakar, Aman, dan Nyaman Dengan Pendekatan Quality Function Deployment," 2019.

[8] P. Yuliarty and H. Ardiwijayanta, "The design of front and back grille of KAD-927 B fan with Nigel Cross Approach at PT. X (A Manufacturer of Household Appliances)," in IOP Conference Series: Materials Science and Engineering, 2018, vol. 453, no. 1, doi: 10.1088/1757-899X/453/1/012035.

[9] F. Sulianta and D. Juju, Data Mining. Elex Media Komputindo, 2010.

[10] R. Prabowo and M. I. Zoelangga, "Pengembangan Produk Power Charger Portable dengan Menggunakan Metode Quality Function Deployment (QFD),” journal.unpar.ac.id, vol. 8, no. 1, 2019, doi: 10.26593/jrsi.v8i1.3187.55-62.

[11] P. Yuliarty, T. Permana, and A. Pratama, "Pengembangan Desain Produk Papan Tulis Dengan Metode Quality Function Deployment (QFD),” J. Ilm. PASTI, vol. 6, no. 1, 2012.

*Correspondence author mail: didi.junaedi@mercubuana.ac.id 